\title{
ANALYSIS OF GREEN GROWTH IN FOREST CONDITIONS
}

\author{
Iveta HAJDÚCHOVÁ ${ }^{1}$ Stanislava Krišt'áková ${ }^{2}$; Christian MIKLER ${ }^{3}$ \\ ${ }^{1}$ Technical university in Zvolen, Department of Forest Economics and Management \\ ${ }^{2}$ Technical university in Zvolen, Department of Forest Economics and Management \\ ${ }^{3}$ Technical university in Zvolen, Department of Forest Economics and Management
}

\begin{abstract}
The aim of the work is the analysis of green growth in the conditions of forestry. Based on the analysis of green growth indicators, we compiled a questionnaire focused on the current situation of LH. The purpose of green growth is to use indicators to implement a strategy in forest companies that, on the one hand, will bring economic growth and, on the other hand, reduce the impact of increasing performance on the environment.Green growth in the conditions of the Slovak Republic deals with increasing economic growth and at the same time tries to minimize the influencing effects of environmental problems such as air quality, the level of recycling, and environmental protection on natural capital. Based on the analysis of secondary sources aimed at approaching the issue of green growth and its indicators, a questionnaire survey was prepared. The questionnaire consisted of openended and closed-ended questions and was divided into four main areas of study of green growth. Based on a questionnaire survey, the situation in forestry in the conditions of the Slovak Republic was mapped. The results show that the introduction of a green growth strategy into forestry is important in terms of long-term economic growth and minimizing environmental impacts.
\end{abstract}

Key words: green growth, indicators of green growth, forestry

\section{Introduction}

Green growth today requires a new perspective on society and the environment. The strategy of green growth is our common future, to which we should move forward and strive to create economic growth and at the same time, to use natural resources as little as possible. Given the worsening climate change that is happening in the world, it is necessary to start thinking about future generations. Green growth promotes long-term economic benefits for the environment. The concept of green growth is nowadays a much-discussed topic that is being addressed by many countries. Green growth in the conditions of the Slovak Republic deals with increasing economic growth and at the same time tries to minimize the negative effects on natural capital. Green growth is considered a practical tool for achieving sustainable development. Currently, the Slovak Republic faces many environmental problems such as air quality, the level of recycling, and the protection of ecosystems. Environmental problems affect not only the economy and employment but also the well-being of people. The purpose of green growth is to use indicators to implement a strategy in forest companies that would increase economic growth on the one hand and reduce the impact on the environment on the other. The aim of the presented article is to map the situation in forest companies on the basis of green growth indicators.

https://doi.org/10.11118/978-80-7509-820-7-0047

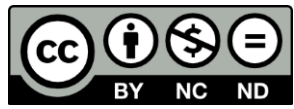




\section{Green growth}

By 2050, the world's population is expected to include 9 billion people, all of whom will still have food, water, and water. The most effective way forward is inclusive green growth, which is environmentally positive, efficient in the use of natural resources, and satisfies the needs of all people (The World Bank 2012). Green growth was the main topic at the Rio +20 conferences on sustainable development in 2012 and will appear in the outcome document ,The World We Want”, which requires a green economy and sustainable development (UN 2012). The concept of green growth has since become a response to a warning about climate change and ecological degradation (Dale et al. 2016). The overall economic expansion, which is measured by GDP, says that green growth can be linked to the ecology of our planet. The idea of green growth was hidden behind sustainable development from the Brundtland Commission until the first conference in Rio, but earlier texts were formulated as ecological modernization or the Environmental Kuznets curve (Ayres et al. 1993, Weizsäcker et al. 1998). The formulation and implementation of a green growth strategy are due to the impact of social and economic flows on ecosystems, which can pose a risk to economic growth and development processes. Natural capital is often underestimated and therefore difficult to manage (OECD 2011b). The goal of green growth is to strengthen investment and innovation, which form the basis of sustainable development and at the same time open up new economic opportunities (Przychodzen et al. 2020, p. 27). To support green growth, it is important to examine the conditions under which it is shaped and its impact on sustainable development. Green and sustainable development is widely recognized as a certain understanding of modern society. This concept represents a state of society where living conditions and the use of natural resources still satisfy human needs without compromising the integrity, stability, and balance of the natural system (Pham et al. 2020, p. 2).

\section{Methodology}

In order to meet the set goal, it was necessary to perform an analysis of secondary sources focused on green growth and its implementation in forestry companies. Secondary sources describe basic concepts such as green growth and its indicators. Based on the analysis of secondary sources, a questionnaire survey was compiled to map the situation in forestry in the conditions of the Slovak Republic. Methods such as summarization, synthesis of knowledge, and analogy were used in individual steps. Finally, the achieved results were evaluated.

The questionnaire survey was compiled on the basis of green growth indicators in the conditions of the Slovak Republic. The questions focused on 4 main indicators, which are described in more detail below. The basic set of research was forest companies, to which the questionnaire was sent online due to the current pandemic situation. 
The OECD Green Growth Indicators are organized according to four main objectives, which relate to a low-carbon economy, the preservation of natural resources, improving the quality of life, implementing policy measures, and seizing economic opportunities. Countries are working to implement green growth policies by promoting new technologies and innovation and using economic instruments. Areas that produce environmental goods and services are maintaining a growing trend in the economy. International financial flows are also being created that support green growth. The main indicators of green growth are (OECD360, Slovak Republic, How is Slovakia doing? 2015):

- Environmental and resource productivity

- Natural asset base

- Environmental quality of life

- Economic instruments and policy measures

Environmental and resource productivity includes the need for efficient use of natural resources or the lowest possible volume of consumed natural resources to create the highest possible economic output. Indicators include $\mathrm{CO} 2$ productivity, energy productivity, and source productivity. Natural asset base says that if the base of natural wealth is reduced, it will point to risk to growth and at the same time it will point to the fact that sustainable growth requires that natural resources be used in the most considerate way possible. Indicators of environmental quality of life monitor the direct effects of the state of the environment on human well-being and also the consequences of dangerous effects of pollution on human health.

The introduction of green economy indicators into forestry ensures further investments, the use of renewable resources, the creation of new jobs, the introduction of more environmentally friendly technologies. Another benefit of these indicators is the creation of green jobs, which allow decisions to be based on the evaluation of forest ecosystem services and the provision of social justice (Majdáková et al. 2021, p. 10).

\section{Results}

The questionnaire method (graphically shown in Graph 1) addressed 1,227 forest companies, of which 109 were answered questionnaires, which represents an $8.88 \%$ return. The results of the questionnaire survey were evaluated as a percentage and the intention was to find out the current situation in forest companies within the implementation of the green growth strategy. 


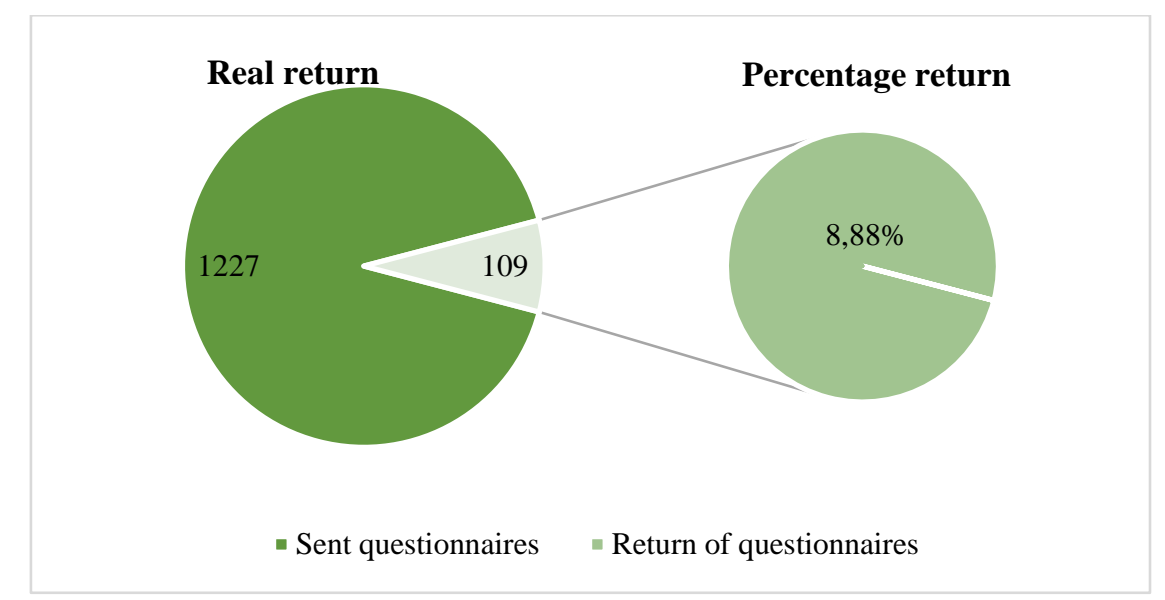

\section{Graph 1 Return on questionnaire survey}

Source: own research

Each of the main indicators of green growth examines a specific area that provides information about a specific indicator. In the analysis of energy savings, we monitored which energy reduction is mostly used by forest companies. The main goal of efficient use of energy is to reduce losses in its use, without lowering the standard of living, as well as reducing the demands on the protection of the natural environment. With the indicator of natural wealth, we analyzed natural resources and their mapping in the conditions of the Slovak Republic. By analyzing the environmental quality of life, we monitored the application of the principles of sustainable development and whether entrepreneurs create internal standards of employee care. As an indicator of economic instruments and policy measures, we have tried to point out that it is necessary to introduce new technologies even more into the production and to implement innovations within the framework of the most environmentally friendly use of natural resources. Table 1 clearly shows the analyzed areas of green growth. 
Table 1 Analyzed areas of green growth

\begin{tabular}{|c|c|}
\hline INDICATOR & ANALYSIS \\
\hline Environmental and resources productivity & Energy saving \\
\hline Environmental quality of life & $\begin{array}{c}\text { Growing stock, wood composition, age } \\
\text { structure, pretocted areas, protected species } \\
\text { of plants and animals, harmful factors }\end{array}$ \\
\hline $\begin{array}{c}\text { Application of the principles of sustainable } \\
\text { development, internal standards of } \\
\text { employee care, contribution to the } \\
\text { construction of recreational function of the } \\
\text { forest }\end{array}$ \\
\hline Economic opportunities & $\begin{array}{c}\text { Integration of new technologies, } \\
\text { certification standards, environmental } \\
\text { labeling of products, environmental } \\
\text { management system, environmental } \\
\text { management and audit scheme, ISO } \\
\text { standards for environment }\end{array}$ \\
\hline
\end{tabular}

Source: own research

Table 2 shows the results of the questionnaire survey according to the evaluated areas. According to individual indicators, which have already been characterized, the situation in forestry is mapped.

For the Environmental and Resource Productivity indicator, we analyzed energy savings, where most respondents reported a reduction in energy losses, which accounted for $42 \%$. The indicator contains the need for efficient use of natural resources. This means that from the smallest possible volume of consumed natural resources to create the highest possible economic output.

The Natural Asset base indicator analyzes the natural wealth that needs to be used in the most environmentally friendly way possible. This indicator analyzes the standing stock, tree composition, age structure, protected areas, protected plant and animal species, and harmful factors. The analysis shows that deciduous forests predominate in the conditions of the Slovak Republic and the main representation is forest beech. The majority of respondents (61\%) state that their company is located in a protected area, which subsequently showed that there are protected species of plants or animals in their territory. Respondents mentioned wind and woodpeckers and wooddestroying insects as the biggest harmful factors, most of which are spruce coats.

For the Environmental Quality of Life indicator, the question was focused on the principles of sustainable development, where up to $88 \%$ of respondents apply these principles. It is considered negative that employers do not have internal standards focused on employee care. More than $68 \%$ of respondents contribute their profits to the recreational function of the forest.

The area of Economic Instruments and Policy Measures was focused on finding out the state of the introduction of new technologies, certification standards, environmental labeling of products, use of EMS, and ISO environmental standards. 
In the analysis of this indicator, it was found that most of the respondents do not use forest certification, environmental labeling of products, EMS, or ISO environmental standards.

Table 2 Results of the questionnaire survey

\begin{tabular}{|c|c|}
\hline Analysis areas & Percentage \\
\hline Reduction of energy losses & $42 \%$ \\
\hline Growing stock of coniferous forest & $0-150 \mathrm{~m}$ \\
\hline Growing stock of deciduous forests & $151-500 \mathrm{~m}$ \\
\hline Wood composition & English Oak and norway spruce \\
\hline Age structure & 10 or more \\
\hline Protected areas & $61 \%$ yes \\
\hline Protected species of plants & $67 \%$ yes \\
\hline Protected species of animals & $79 \%$ yes \\
\hline Harmful factors & $\begin{array}{l}\text { Wind, bark beetles and wood- } \\
\text { destroying insects }\end{array}$ \\
\hline Application of the principles of SD & $88 \%$ yes \\
\hline Internal standards of employee care & $67 \%$ no \\
\hline $\begin{array}{l}\text { Contribution to the construction of } \\
\text { recreational function of the forest }\end{array}$ & $0-5 \%$ \\
\hline Integration of new technologies & $59 \%$ yes \\
\hline Certification standards & $67 \%$ no \\
\hline Environmental labeling of products & $83 \%$ no \\
\hline Environmental management system & $96 \%$ no \\
\hline Environmental management and audit scheme & $99 \%$ no \\
\hline ISO standards for environment & $92 \%$ no \\
\hline
\end{tabular}

Source: own research 


\section{Discussion}

Multifactor productivity and resource efficiency depend on the technical refurbishment of forestry and the logging industry, the production of high valueadded products, the use of logging waste, and other rational uses of non-timber forest resources (Knyazeva et al. 2016, p.27). According to national socio-economic conditions, the introduction of green principles contributes to increasing the role of the forestry sector in increasing the well-being of the population, receiving income from the production of timber and timber products, and providing ecosystem services. The forestry sector, which fulfills socio-ecological-economic functions, expands intersectoral cooperation with organizations and structures of the environmental and social sphere, agriculture, and local people (Yakovleva et al. 2019 , p. 9). In the concept of a green economy, the forest acts not only as a raw material component of the production process but also as a part of the ecological and social infrastructure of territorial development. This makes it possible to provide a long-term and multifaceted solution to the state of forest resources, the rational use and improvement of the environment, with the involvement of a wide range of stakeholders. When developing a project to implement green principles in forestry, it is necessary to raise the awareness of residents and local people about the processes of improving the national forest policy and system of relations in forests (Yakovleva et al. 2019, p. 9). According to Hallegatte (2011), the goal of green growth strategies is to reduce development risk and thus increase the resilience of the economic system. The loss of natural capital can be compensated by other types of capital in the short term, but not in the long term. An example could be the increase in the use of fertilizers to compensate for soil degradation - a short - term solution that is not sustainable in the long term. The introduction of green economy principles in the forest sector enables to provide the inflow of additional investments, sustainable production, and consumption of forest products, and consumption of forest products, the introduction of environmentally friendly and resource-efficient production technologies, and consumption patterns of forest products, including waste recycling and wood consumption (Yakovleva et al. 2019, p. 9). The meaning and consequences of Green Growth and De growth for the firm are still heavily understudied, with studies looking at firm or supply chain sustainability focusing on the Circular Economy instead (Belmonte-Ureňa el al. 2021). Authors Vazquez-Brust and Plaza Úbeda (2020) use a survey of 500 Argentinean firms and multiple discriminant analysis to study the characteristics of firms that have environmental performance going beyond the requirements of regulation in environmental protection. However, only managers with green growth beliefs allowed discrimination beyond firms not complying with regulations and those which were complying. In alignment with the conclusions by Khairunnessa et al. (2021) and Piao et al. (2021), the results of this paper show that in countries with weak regulatory institutions, the "Green Growth State" can only protect the environment if there is strong ecological citizenship with managers endorsing the pro-environmental paradigms of development proposed by green growth. 


\section{Conclusion}

The present contribution deals with indicators of green growth and their application in forestry. The aim of the paper is to approach the issue of green growth and analyze its indicators in forestry. Based on the analysis of secondary sources aimed at approaching the issue of green growth and its indicators, a questionnaire survey was prepared. The questionnaire consisted of open-ended and closed-ended questions and was divided into four main areas of study of green growth. Based on a questionnaire survey, the situation in forestry companies in the Slovak Republic was mapped. Negative results include the fact that most respondents do not use certification standards, product eco-labeling, EMS, or ISO environmental standards. We consider the positive results to be the fact that most respondents use the implementation of the principles of TUR and try to implement new technologies into production. The results show that the introduction of a green growth strategy into forestry is important in terms of long-term economic growth and minimizing environmental impacts.

\section{Ackonwledgment}

This contribution is a partial output of projects: APVV no. 18-0520 „Innovative methods of performance analysis of forestry-wood complex using the principles of green growth" and IPA 9/2021 „Mapping the current situation in the field of green growth in the wood processing industry in Slovakia".

\section{References}

1. Ayres, R. U., Simonis, U. E. (1993): Industrial metabolism: restructuring for sustainable development, Tokio, New York: UN University Press

2. Belmonte-Ureña, L.J.; Plaza-Úbeda, J.A.; Vazquez-Brust, D.; Yakovleva, N. Circular economy, degrowth and green growth as pathways for research on sustainable development goals: A global analysis and future agenda. Ecol. Econ. 2021, 185, 107050. [CrossRef]

3. Dale, G., Mathai, M, V., and De Oliveira, J. A. P., EDS. (2016): Green growth: odeology, political economy and the alternatives, London, Zed Books Ltd.

4. Enviromagazín (1/2013): Národný súbor indikátorov zeleného rastu v SR,

5. Knyazeva, G. A., Kirusheva, N. Y. (2016): Transition to a Green Economy on the Example of Innovative Development of the Regional Forest Complex, St Petersburg State University, Journal of Economic Studies, Issue 2Department of World and National Economy, Voronezh State University of Forestry and Technologies named after G F Morozov, 8 Timiryazeva Street, Voronezh 394087, Russian Federation

6. Hallegatte, S., G. Heal, M. Fay, D. Treguer. 2011. "From Growth to Green Growth: A Framework." Background paper for the Flagship Report on Green Growth, Policy Research Working Paper 5872, World Bank, Washington, DC

7. Khairunnessa, F.; Vazquez-Brust, D.A.; Yakovleva, N. A review of the recent developments of green banking in Bangladesh. Sustain. 2021, 13, 1-21, doi:10.3390/su13041904.

8. Majdáková, A., Hajdúchová, I., Giertliová, B., Mikler, Ch. (2021): Uplatňovanie princípov zelenej ekonomiky $v$ prosperujúcich podnikoch lesného hospodárstva, In Analýza príčin bankrotu malých a stredných podnikoch na Slovensku: zborník vedeckých príspevkov z 
riešenia projektu VEGA č. 1/0468/18, s. 200-209, ISBN 978-80-557-1821-7. APVV-18-0520, VEGA $1 / 0468 / 18$

9. OECD, (2011B): Towards Green Growth Paris: Organization for Economic Cooperation and Development

10. Organisation for Economic Cooperation and Development (2015) OECD360, Ako sa dari Slovensku

11. Pham, D, T., Noi, N., Sharma, K, A., Dao, D. V. (2020): Advaned Nanomaterials for Green Growth, Volume 2020, Article ID 9567121, 2 pages,

12. Piao, R.S.; Silva, V.L.; Del Aguila, I.N.; de Burgos Jiménez, J. Green growth and agriculture in Brazil. Sustain. 2021, 13, 1-13, doi:10.3390/su13031162.

13. Plaza-Úbeda, J.A.; Pérez-Valls, M.; Céspedes-Lorente, J.J.; Payán-Sánchez, B. The contribution of systems theory to sustainability in degrowth contexts: The role of subsystems. Syst. Res. Behav. Sci. 2020, 37, 68-81.

14. Przychodzen, W.; Leyva-de la Hiz, D.I.; Przychodzen, J. (2020): First-mover advantages in green innovation- Opportunities and threats for financial performance: A longitudinal analysis. Corp. Soc. Responsib. Environ. Manag. 2020, 27, 339-357.Glowacka M. (2010), Title of the publication, Publisher, Place of publication.

15. The World Bank (2012): Inclusive Green Growth: Pthe Pathway to Sustainable Development,

16. Weizsäcker, E.U., Lovins, A.B., and Lovins, L.H. (1998): Factor four: doubling wealth, halving resource use. Club of Rome. London: Earthscan.

17. Yakovleva, A. E., Subhonberdiev, Sh. A. (2019): Implementation of "green" economy principles in the forest sector, Department of World and National Economy, Voronezh State University of Forestry and Technologies named after G F Morozov, 8 Timiryazeva Street, Voronezh 394087, Russian Federation 